\title{
Quality assessment of Nigerian honeys sourced from different floral locations
}

\author{
Ndife Joel*, Kida Fatimah, Makarfi Tijjani \\ Department of Food Technology, Kaduna Polytechnic, Nigeria \\ Email address: \\ jothel2000@yahoo.com (J. Ndife)
}

To cite this article:

Ndife Joel, Kida Fatimah, Makarfi Tijjani. Quality Assessment of Nigerian Honeys Sourced from Different Floral Locations. Journal of Food and Nutrition Sciences. Vol. 2, No. 4, 2014, pp. 162-167. doi: 10.11648/j.jfns.20140204.20

\begin{abstract}
Comparative studies on the quality of honey obtained from different floral locations in Nigeria were investigated. Parameters such as physical properties, chemical, mineral, microbial contents and antimicrobial activity as well as organoleptic quality were evaluated. The results of the physico-chemical properties show the following range of values for acidity $(1.36-1.55 \%)$, soluble solids $(80.96-82.00 \%)$, specific gravity $(1.41-1.44)$ and sweetness index $(52.52-$ $62.73)$. While the proximate values were: moisture $(15.69-18.41 \%)$, protein $(0.90-1.15 \%)$, fat $(0.12-0.21 \%)$, ash $(0.26-$ $0.38 \%)$ and carbohydrate $(79.94-82.71 \%)$. Potassium $(55.31 \mathrm{mg} / 100 \mathrm{~g})$ and calcium $(5.14 \mathrm{mg} / 100 \mathrm{~g})$ were the dominant minerals in the honey samples. The highest microbial count was observed in sample NSK $\left(1.4 \pm 0.14 \times 10^{2} \mathrm{cfu} / 100 \mathrm{~g}\right)$. There were no observable coliform growths in all the samples. All the honey samples exhibited antibacterial activities with clear zones that range from 2.05-6.10mm. Honey samples KAD and ABJ had the best overall acceptance scores of 8.49 and 8.27 respectively.
\end{abstract}

Keywords: Honey, Proximate, Mineral, Antibacterial, Organoleptic

\section{Introduction}

Honey is a delicious viscous sweetener made naturally by bees for their own nourishment from the nectar or secretion of flower plants. Honey has a long history of human consumption as a natural food source and is also used as ingredients in various food preparations, in both alcoholic and non-alcoholic beverages as sweeteners and in confectionaries as flavouring agents (Adebiyi et al., 2004; Durrani et al., 2011; Eleazu et al., 2013). Although the food ranking system did not qualify honey as a dense source of traditional nutrients apart from the sugar content, it did emerge as a veritable source of vitamin $\mathrm{B}_{2}$, vitamin $\mathrm{B}_{6}$, iron and managanese (Alvarez-Suarez et al, 2010; Vanhanen et al., 2011).

Thus, honey has been used since ancient times not only as food but as a medicine and in cosmetics. Honey has been credited for many biological and therapeutic purposes such as: treatment of colds, skin wounds and various gastrointestinal diseases. This beneficial role is attributed to both the antimicrobial and anti-inflammatory properties of honey that arise from the low acid nature, high sugar, mainly of glucose and fructose components (Amril and
Ladjama, 2013). Raw honey contains an enzyme called glucose oxidase which combines with water to produce hydrogen peroxide, a mild antiseptic (Amiot et al., 1989). In addition, several enzymes (invertase, glucose oxidase, catalase, phosphatases) found in honey also help in the healing process (Khalil et al., 2010). Honey also contains phytochemicals such as flavonoids and other polyphenols that makes it a potential functional ingredient and as antibacterial agents (Khalil et al., 2010; Gulfraz et al., 2011; Ramanauskiene et al., 2012).

The composition and quality of honey vary, depending on the climatic region, whether wet or dry, the environmental temperature, the type of botanical plant used to produce it, the honey bees species, the sugar composition, the treatment of honey during extraction, processing and subsequent storage conditions (Alvarez-Suarez , 2010; Amril and Ladjama, 2013). Honey comes in a range of colours including white, amber, red, brown and almost black (Eleazu et al., 2012). Its flavor and texture also vary with the flower nectar from which it was made. While the most commonly available honeys are made from clover, alfalfa, heather and acacia flowers, honey can be made from a variety of different flowers including thyme and invender (Azenedo et al., 2003; Alvarez-Suarez, 2010). 
Commercial honeys are sold in individual containers or in bulk. They are available as raw or processed honey. The latter is usually pasteurized, clarified, or filtered and at times fortified. Raw honey is of the highest organic quality and is regarded as $100 \%$ pure (Amiot et al., 1989; Ramanauskiene et al., 2012 ).

The microorganisms of interest in honey are those that can withstand the concentrated sugar content, acidity and antimicrobial action of honey. They include certain yeasts and spore - forming bacteria (coliforms), indicative of the sanitary condition of the honey (Eleazu et al., 2012).

In Nigeria the demand for honey is ever increasing because of the nutritional and medicinal benefits. This is supported by the huge botanical endowment and the natural biodiversity, which makes the production very lucrative. However, reports of the physico-chemical and sensory quality of available honey varies for different locations (Snowdon and Cliver, 1996; Gulfraz et al., 2011). This is compounded by the preponderance of adulterated honeys, whose qualities are difficult to ascertain. It is thus pertinent that the dealers and consumers be well informed of the quality of the honey that they are purchasing.

The purpose of this study therefore is to evaluate and provide more data on the physico-chemical composition, microbial quality, anti-microbial activities and organoleptic attributes of honey samples from different geographic floral locations in Nigeria.

\section{Materials and Methods}

\subsection{Collection of Honey Samples}

Five honey samples were each sourced from different geographic regional locations in Nigeria. The samples were collected from different honey markets in Kaduna (northern region), Abuja (central region), Nsukka (eastern region) and Ibadan (western region) of the country, and were labeled as samples KAD, ABJ, NSK, and IBD respectively. The control sample IMP which served as control was an imported brand from USA. All the honey samples were stored at ambient temperature, in sample plastic-bottles with tight-fitting lids, during the period of analytical investigation.

\subsection{Physico-Chemical Analysis}

The $\mathrm{pH}$, brix (soluble solids) and specific gravity of the juice samples were measured using standardized instrumental methods (AOAC, 1990). The acidity was determined by titration against $0.1 \mathrm{M}$ sodum hydroxide using phenolphalein as indicator (Jacobs, 1999). The sweetness and astringency indexes were calculated as the ratio of soluble solids to acidity and vice versa (Wardy et al., 2009). The proximate composition of the honey samples were determined as described by Onwuka (2005): The moisture contents by indirect distillation drying method; Ash content by the muffle furnace ignition method; Fat content through the solvent extraction method in a continuous reflux system using the soxtlet apparatus. The protein contents were determined by the formal titration method. While the carbohydrate and energy contents were determined by recommended mathematical procedures.

\subsection{Mineral Assay}

The mineral contents of honey, including $\mathrm{K}, \mathrm{Na}, \mathrm{Ca}, \mathrm{Mg}$, and $\mathrm{Fe}$, were quantitatively determined using an atomic absorption spectrophotometer, after digestion by the wet ashing method (Escuredo et al., 2011).

\subsection{Microbiological Analysis}

The determination of the microbial contamination (mesophilic aerobic bacteria, coliforms, yeast and mold counts) in the products was performed by the method outlined in compendium of methods for the microbiological examination of foods (AMPH, 1992) with some modifications.

\subsection{Antibacterial Activity}

Antibacterial activities of the different honeys were determined by direct assay procedure (Gulfraz et al, 2011). Nutrient agar plates were swabbed with the respective overnight culture of 4 clinically important bacterial strains (S. aureus, E. coli, P. aeruginosa and B. subtilis) obtained from the National Institute of Trypanosomiasis Research (NITR), Kaduna. Sterile $6 \mathrm{~mm}$ diameter filter paper disc impregnated with the honey samples, were placed on the pre-seeded agar and incubated at room temperature for 24 hours. The anti-bacterial activity was observed as increased diameter $(\mathrm{mm})$ of clear zone of growth inhibition.

\subsection{Sensory Evaluation}

Sensory evaluation of the composite bread samples were carried out by 25 panelists on a 9 point hedonic scale for different parameters such as colour, aroma, taste, texture and overall acceptability as described by Iwe (2010).

\subsection{Statistical Analysis}

The results were statistically analyzed after triplicate sampling and their mean values and standard deviation presented. The sensory evaluation data was also statistically analyzed using the analysis of variance (ANOVA) and the Duncan Multiple range test with significance level at $\mathrm{p}<0.05$ (Ihekoronye and Ngoddy, 1985).

\section{Results and Discussion}

\subsection{Physico-Chemical Properties}

The physico-chemical parameters analysed for the honey samples are summarised in Table 1.

The $\mathrm{pH}$ values of the honey samples from different sources investigated revealed that all the samples were within the acidic range of $\mathrm{pH}$ of 4.10 to 4.58 . The $\mathrm{pH}$ values were within the acceptable range specified by Codex 
Alimentarius (2001). This corroborate with the range of values (1.36 to 1.55$)$ obtained on the acidity of the different honey samples. In general, honey is acidic in nature irrespective of its geographical origin (Adebiyi et al, 2004; Viuda-Martos et al., 2010). The acidic pH of honey might be due to the constituent acids, mainly gluconic acid and minerals. The $\mathrm{pH}$ values of honey are of great importance during storage, since the acidity can influence the texture, stability and shelf life of honey (Amri and Ladjama, 2013).

Table 1. Physico-chemical properties of different honey samples

\begin{tabular}{llllll}
\hline Honey Samples & & & & \\
\hline Parameters & KAD & ABJ & NSK & IBD & IMP \\
\hline pH & $4.10 \pm 2.01$ & $4.30 \pm 2.05$ & $4.35 \pm 1.80$ & $4.47 \pm 1.93$ & $4.58 \pm 2.10$ \\
Acidity \% & $1.55 \pm 1.10$ & $1.50 \pm 1.00$ & $1.30 \pm 1.04$ & $1.42 \pm 1.07$ & $1.36 \pm 1.05$ \\
Specific gravity & $1.43 \pm 0.18$ & $1.42 \pm 0.15$ & $1.44 \pm 0.52$ & $1.44 \pm 0.10$ & $1.41 \pm 0.16$ \\
Soluble solids \% & $81.40 \pm 2.53$ & $82.00 \pm 2.24$ & $81.55 \pm 2.30$ & $80.96 \pm 2.01$ & $81.10 \pm 2.51$ \\
Total solids \% & $83.24 \pm 1.12$ & $84.31 \pm 1.20$ & $82.10 \pm 1.24$ & $82.65 \pm 1.23$ & $82.95 \pm 1.20$ \\
Sweetness Index & $52.52 \pm 0.55$ & $54.66 \pm 0.50$ & $62.73 \pm 0.52$ & $57.01 \pm 0.45$ & $59.63 \pm 0.50$ \\
Astringency Index & $0.06 \pm 0.02$ & $0.05 \pm 0.02$ & $0.03 \pm 0.01$ & $0.04 \pm 0.01$ & $0.03 \pm 0.01$ \\
\hline
\end{tabular}

${ }^{\mathrm{a}}$ Data are mean values of triplicate determinations \pm standard deviation

The mean refractive index of the honey samples was 1.43 , with a range of $1.41-1.44$. This value is similar to those reported by Adebiyi et al., (2004).The refractive index could be used to determine the level of adulteration and hence quality, based on the specification (Adebiyi et al., 2004).

The analysed honey samples had total solid values ranging from 82.10 to $84.31 \%$ and soluble solid content in the range of 80.96 to $82.00 \%$. similar to the results obtained by Viuda-Martos et al., (2010) on honey samples from different origins. Total solid is a measure of dissolved solids in the honey samples. In all the honey samples, the total soluble solid values were generally more than $82 \%$. Honey with total soluble solids greater or equal to $81.4 \%$ is considered of higher grade (A and B), while that falling between $80 \%$ and $81.3 \%$ is considered to be of lower grade C (USDA, 1985; Nyau et al., 2013). The soluble solids content of honey is a reliable index of adulteration (ViudaMartos et al., 2010) and a major factor for the categorization of the glycemic index, a major concern for diabetic persons.

The sweetness index and astringency of the different honey samples range from 52.52 to 57.01 and 0.03 to 0.06 respectively. The ratio of sugars to acids and vice-versa gives an accurate prediction of the tartness and sweetness of acid foods which influence organoleptic perception (Wardy et al., 2009). Foods with sweetness index greater than 19 are regarded as sweet and less acid by taste (Wardy et al., 2009).

\subsection{Proximate Composition}

The results of the proximate composition of the different honey samples are shown in Table 2.

The moisture content of honey samples analyzed varied from 15.69 to $18.41 \%$. The average moisture content of all the samples was below $21 \%$ which is regarded as good according to the Codex Alimentarius (2001) specifications. The moisture content of honey is one of the criteria that determine the shelf stability of honey (Azenedo et al., 2003; Ezeama, 2007). Thus the higher the moisture, the higher the probability that honey will ferment upon storage by osmotolerant yeasts (Viuda-Martos et al., 2010). A high moisture content of honey is also an indicator of adulteration (Nyau et al., 2013).

Table 2. Proximate analysis of different honey samples

\begin{tabular}{llllll}
\hline Parameters & KAD & ABJ & NSK & IBD & IMP \\
\hline Moisture & $16.76 \pm 2.10$ & $15.69 \pm 1.94$ & $17.90 \pm 2.12$ & $17.35 \pm 2.05$ & $18.41 \pm 1.90$ \\
Protein & $1.04 \pm 0.31$ & $1.10 \pm 0.41$ & $0.90 \pm 0.28$ & $1.03 \pm 0.25$ & $1.15 \pm 0.30$ \\
Fat & $0.20 \pm 0.02$ & $0.20 \pm 0.03$ & $0.14 \pm 0.01$ & $0.12 \pm 0.01$ & $0.21 \pm 0.03$ \\
Ash & $0.38 \pm 0.04$ & $0.30 \pm 0.03$ & $0.26 \pm 0.05$ & $0.34 \pm 0.04$ & $0.29 \pm 0.03$ \\
Carbohydrate & $81.80 \pm 3.15$ & $82.71 \pm 3.10$ & $80.80 \pm 2.96$ & $81.16 \pm 3.38$ & $79.94 \pm 3.32$ \\
Energy (Kcal/100g) & $333.16 \pm 4.80$ & $337.04 \pm 5.10$ & $328.06 \pm 4.32$ & $329.84 \pm 4.20$ & $326.25 \pm 4.15$ \\
\hline
\end{tabular}

*Data are mean values of triplicate determinations \pm standard deviation

Very low values were recorded for the protein and fat contents of the different honey samples, which range from 0.90 to $1.15 \%$ and 0.14 to $0.21 \%$ respectively. The results obtained were in agreement with that reported by other authors (Azenedo et al., 2003; Alvarez-Suarez et al., 2010).
High fat content makes foods to be susceptible to rancid spoilage during storage (Durrani et al., 2011).

The values obtained for the ash content varied from 0.30 to $0.40 \%$, with honey $\mathrm{KAD}$ having the highest ash content $(0.38 \%)$ while honey sample NSK had the least $(0.26 \%)$. 
Ash content is a reflection of the total inorganic minerals that are present in a sample after incineration (Vanhanen et al., 2011). The low ash values recorded fell within the range typical of natural nectar honeys (Nyau et al, 2013) and not of honeydew honeys, which are have been reported to have high ash content (Viuda-Martos et al. 2010). The Codex Alimentarius Commision (2001) standard specified an ash content of not more than $0.6 \%$ for normal honey.

The carbohydrate and energy contents of the honey samples were in the range of 79.94 to $82.71(\%)$ and 326.2 to $328.06(\mathrm{kcal} / 100 \mathrm{~g})$ respectively. Glucose and fructose are the major component of carbohydrate found in honey and the ratio of their preponderance is a factor in determining adulteration levels and the honeys suitability for diabetes management (Doner , 1997; Nombre et al., 2010; Escuredo et al., 2011).

\subsection{Mineral Composition}

The mineral content of the honey samples analyzed is presented in Table 3. The total mineral content of the honey samples range from 49.69 to $68.30(\mathrm{mg} / 100 \mathrm{~g})$ with sample ABJ from Abuja having the highest potassium content (55.31 mg/100g) while that from Nsukka (sample NSK) was the least $(37.28 \mathrm{mg} / 100 \mathrm{~g})$. The results obtained were in agreement with that reported by Vanhanen et al., (2011) on the dominance of potassium.

Table 3. Mineral analysis of different honey samples

\begin{tabular}{llllll}
\hline Honey samples $(\mathbf{m g} / \mathbf{1 0 0 g})$ & & & & \\
\hline Parameters & KAD & ABJ & NSK & IBD & IMP \\
\hline Sodium & $3.79 \pm 0.50$ & $3.86 \pm 0.36$ & $3.99 \pm 0.50$ & $4.20 \pm 0.85$ & $4.60 \pm 0.42$ \\
Potassium & $50.10 \pm 0.62$ & $55.31 \pm 0.83$ & $37.28 \pm 1.01$ & $43.42 \pm 1.06$ & $45.65 \pm 0.98$ \\
Calcium & $6.81 \pm 0.42$ & $5.54 \pm 0.25$ & $5.10 \pm 0.22$ & $4.05 \pm 0.36$ & $4.18 \pm 0.46$ \\
Magnesium & $3.12 \pm 0.10$ & $2.86 \pm 0.14$ & $2.71 \pm 0.20$ & $2.60 \pm 0.16$ & $2.80 \pm 0.38$ \\
Iron & $1.12 \pm 0.04$ & $0.73 \pm 0.08$ & $0.61 \pm 0.06$ & $0.52 \pm 0.08$ & $0.85 \pm 0.05$ \\
Total & $64.94 \pm 2.35$ & $68.30 \pm 2.50$ & $49.69 \pm 2.46$ & $54.79 \pm 2.73$ & $58.08 \pm 2.28$ \\
\hline
\end{tabular}

*Data are mean values of duplicate determinations \pm standard deviation

The results show that these Nigerian honey samples are quite rich in minerals. The percentage mineral content is considered as a quality criterion indicating the possible botanical origin of honey (Vanhanen et al., 2011). The differences in mineral content majorly depend on the type of soil in which the original nectar bearing plant was located (Alvarez-Suarez, 2010; Amril and Ladjama, 2013).
The mean bacteria counts of the honey samples that were studied, as shown in Table 2, ranged from $1.3 \times 10^{1}$ to $1.4 \times 102(\mathrm{cfu} / 100 \mathrm{ml})$ with the honey from Nsukka (sample NSK) having the highest loads while that from Kaduna (KAD) had the least load. The microbiological quality of honey will give an indication of the hygienic conditions under which the product was processed, handled and stored.

\subsection{Microbial Content}

Table 4. Microbial analysis of different honey samples

\begin{tabular}{|c|c|c|c|c|c|}
\hline \multicolumn{6}{|c|}{ Honey samples (cfu/100g) } \\
\hline Parameters & KAD & ABJ & NSK & IBD & IMP \\
\hline TVC & $1.1 \pm 0.21 \times 10^{1}$ & $1.3 \pm 0.20 \times 10^{1}$ & $1.5 \pm 0.14 \times 10^{2}$ & $1.4 \pm 0.12 \times 10^{2}$ & $1.0 \pm 0.11 \times 10^{2}$ \\
\hline $\mathrm{TCC}$ & Nil & Nil & NIL & NIL & NIL \\
\hline TYMC & $1.0 \pm 0.13 \times 10^{1}$ & $1.2 \pm 0.15 \times 10^{1}$ & $5.1 \pm 0.20 \times 10^{1}$ & $3.5 \pm 0.18 \times 10^{1}$ & $3.0 \pm 0.15 \times 10^{1}$ \\
\hline
\end{tabular}

TVC-Total Viable Counts; TCC- Total Coliform counts; TYMC- Total Yeast \& Mould Counts; ${ }^{b}$ Data are mean values of triplicate determinations \pm standard deviation

The yeast and mould contents of the honey samples also ranged from $1.0 \times 10^{1}$ to $5.1 \times 10^{1}$. The low microbial loads of honey samples KAD and ABJ could be attributed to their low moisture and $\mathrm{pH}$ values and high amounts of total soluble sugars and possibly phenolic compounds and their synergistic inter-actions (Alvarez-Suarez et al., 2010). Yeasts and moulds and spore-forming bacteria (coliforms) have been implicated to survive in honey and are indicative of the sanitary quality of the honey (Ezeama, 2007; Eleazu et al., 2013). There were no coliform bacteria detected in the honey samples.

\subsection{Antibacterial Activity}

The results of the assessment of the antimicrobial activity of the honey samples against various bacterial strains are cited in Table 5. The honey samples showed varying activity against the tested bacteria as shown by the different zones of inhibition. The maximum zones of bacterial inhibition were recorded for $E$. coli $(6.10 \mathrm{~mm})$ and $S$. aureus $(5.85 \mathrm{~mm})$ by honey samples from Abuja (ABJ) and Kaduna (KAD) respectively. While the least zones of inhibition were observed for B. subtilis by honey samples from Nsukka (NSK) and Ibadan (IBD). 
Table 5. Antibacterisl activity of different honey samples

\begin{tabular}{llllll}
\hline Honey samples $(\mathbf{m m})$ & & & & \\
\hline Microorganisms & KAD & ABJ & NSK & IBD & IMP \\
\hline S. aureus & $5.85 \pm 0.30$ & $5.10 \pm 0.22$ & $1.70 \pm 0.20$ & $2.35 \pm 0.35$ & $4.15 \pm 0.25$ \\
E. coli & $5.30 \pm 0.22$ & $6.10 \pm 0.30$ & $2.10 \pm 0.26$ & $2.75 \pm 0.35$ & $5.10 \pm 0.35$ \\
P. aeruginosa & $5.05 \pm 0.20$ & $4.60 \pm 0.28$ & $2.40 \pm 0.34$ & $3.10 \pm 0.28$ & $3.95 \pm 0.34$ \\
B. subtilis & $3.20 \pm 0.27$ & $2.65 \pm 0.34$ & Nil & Nil & $2.05 \pm 0.30$ \\
\hline a Data are mean values of triplicate determinations \pm standard deviation & & &
\end{tabular}

The factors responsible for the antimicrobial activity of honeys are high osmolarity (Snowdon and Cliver, 1996; Eleazu et al, 2013); acidity, the enzymatic formation of hydrogen peroxide (Baltrusaityte et al., 2007; Al-Habsi and Niranjan, 2012).); bee-origin, floral source and possible contribution of phytochemicals (Snowdon and Cliver, 1996; Alvarez-Suarez et al., 2010). It is possible that the honeys with high antimicrobial activities could contain high quantities of polyphenols or glucose oxidases or both as these have also been reported to possess antibacterial properties (Khalil et al., 2010). Thus for optimum antibacterial activity, honey should be stored in a cool, dark place and be consumed when fresh.

\subsection{Sensory Evaluation}

The mean sensory scores on the organoleptic preference for different honey samples are shown in Table 6.

Table 6. Sensory analysis of different honey samples

\begin{tabular}{llllll}
\hline Honey samples & \multicolumn{1}{l}{} \\
\hline Parameters & KAD & ABJ & NSK & IBD & IMP \\
\hline Colour & $8.53^{\mathrm{a}}$ & $8.14^{\mathrm{a}}$ & $6.65^{\mathrm{c}}$ & $6.35^{\mathrm{c}}$ & $7.35^{\mathrm{b}}$ \\
Taste & $8.50^{\mathrm{a}}$ & $8.15^{\mathrm{a}}$ & $6.50^{\mathrm{c}}$ & $6.82^{\mathrm{c}}$ & $7.72^{\mathrm{b}}$ \\
Aroma & $8.61^{\mathrm{a}}$ & $8.45^{\mathrm{a}}$ & $7.10^{\mathrm{c}}$ & $7.65^{\mathrm{b}}$ & $7.93^{\mathrm{b}}$ \\
Texture & $7.64^{\mathrm{a}}$ & $7.50^{\mathrm{b}}$ & $6.13^{\mathrm{b}}$ & $6.48^{\mathrm{b}}$ & $7.49^{\mathrm{a}}$ \\
Overall acceptability & $8.49^{\mathrm{a}}$ & $8.27^{\mathrm{a}}$ & $6.32^{\mathrm{c}}$ & $6.38^{\mathrm{c}}$ & $7.60^{\mathrm{b}}$ \\
\hline
\end{tabular}

"Means within a row with different letters are significantly different at $\mathrm{P}<0.05$.

There were significant differences $(p<0.05)$ in the sensory attributes analyzed between the different types of honey. Honey samples from Kaduna (KAD) and Abuja $(\mathrm{ABJ})$ had the highest scores of 8.53 and 8.14 respectively, for appearance (colour) attribute. Similar trends were obtained in panelists' scores on taste and aroma. Colour is usually an indication of flavour concentration. Usually a lighter colour will indicate a milder flavour (Amri and Ladjama, 2013). Darker honeys were also reported to have higher $\mathrm{pH}$, phytochemicals , antioxidant activities, mineral content but lower amount of sugars than lighter honeys (Adebiyi et al., 2004; Escuredo et al., 2011; Eleazu et al., 2013).

The lowest scores of 6.13 and 6.48 were recorded for texture (smoothness) of the honey samples from Ibadan (IBD) and Nsukka (NSK) respectively. The texture of honey is a function of the viscosity. The viscosity of honey is affected greatly by temperature and water content and to a lesser extent by the composition of the honey (Durrani et al., 2011). Honey samples from Kaduna (KAD) and Abuja (ABJ) had the best overall acceptance scores of 8.49 and 8.27 respectively.

\section{Conclusion}

The results of this study show the variability of some quality characteristics of honey samples from the different regions of Nigeria. The honeys were mostly of good quality when compared with Codex Alimentarius (2001) honey specifications. The honey samples from the northern region of Nigeria had the best overall acceptability ratings.

However, the difference in composition and sensory quality of the honey samples may also be influenced by factors such as: geographical and botanical origin of the flora, type and activity of the bee, the extraction technique employed and the storage conditions (Escuredo et al., 2011; Al-Habsi and Niranjan, 2012; Eleazu et al., 2013), which could serve as basis for further research.

\section{References}

[1] Adebiyi, F.M., Akpan, I., Obiajunwa, E.I. and Olaniyi, H.B. (2004). Chemical physical characterization of Nigeria honey. Pakistan J. Nutr., 3: 278-281.

[2] Al-Habsi, N. and Niranjan, K. (2012). Effect of high hydrostatic pressure on antimicrobial activity and quality of manuka honey. Food Chemistry, 135: 1448-1454.

[3] Alvarez-Suarez, J., Tulipani Romandini, S., Bertoli, E. and Battino, M. (2010). Contribution of honey in nutrition and human health: a review. Mediterr J Nutr Metab., 3:15-23.

[4] Amiot, M.J., Aubert, S., Gonnet, N. and Tacchini, M. (1989) Phenolic composition of honeys and group qualification. Journal of Food Chemistry, 20: (2) 115-125.

[5] A.M.P.H. (1992). Compendium of methods for the microbiological examination of foods. Washington DC: American Public Health Association.

[6] Amril, A. and Ladjama, A. (2013). Physicochemical characterization of some multifloral honeys from honeybees Apis mellifera collected in the Algerian northeast. African Journal of Food Science, 7(7): 168-173. 
[7] A.O.A.C (1990). Official Methods of Analysis, 17th ed. Association. of Official Analytical Chemists. Washington, D.C.

[8] Azenedo, L., Azeredo, M., De Souza, S. and Dautra, L. (2003). Protein content and physiochemical properties in honey samples of Apis Mellefera of different floral origins. Food Chemistry. 80(2) 249- 254.

[9] Baltrusaityte, V., Venskutonis, P. and Ceksteryte, V. (2007). Antibacterial activity of honey and beebread of different origin against S. aureus and S. epidermidis. Food Technol. Biotechnol., 45 (2): 201-208.

[10] Codex Alimentarius (2001). Draft revised standard standard for honey (at step 10 of the codex procedure). Codex Alimentarius Commission, FAO, Rome, Alinorm, 25, 19-26.

[11] Doner, W. (1997). The sugars of honey - a review, Journal of the Science of Food and Agriculture, 28: 443-456.

[12] Durrani, A., Srivastava, P. and Verma, S. (2011). Development and quality evaluation of honey based carrot candy. J. Food Sci Technol., 48(4): 502-505.

[13] Eleazu, C.O., Iroaganachi, M. and Okoronkwo, J. (2013). Determination of the physico-chemical composition, microbial quality and free radical scavenging activities of some commercially sold honey samples in Aba, Nigeria: 'The effect of varying colors' J. Nutr. Food Sci., 3(2): 189.

[14] Escuredo, O., Seijo, M. and Fernandez-Gonzalez, M. (2011). Descriptive analysis of rubus honey from the north-west of Spain. International Journal of Food Science and Technology, 46: 2329-2336.

[15] Ezeama, C.F. (2007). Food Microbiology, Fundamental and Applications. Natural Prints Limited, Lagos, Nigeria.

[16] Gulfraz, M., Itkihar, F., Imran, M., Zeenat, A., Asif, S. and Shah, I. (2011). Composition analysis and antrimicrobia activity of various honey types. Pakistan. International Journal of Food Science and Technology, 46: 263-267.

[17] Ihekoronye, A.I. and Ngoddy, P.O. (1985). Integrated Food science and Technology for the tropics. Macmillan publishers Ltd, London, pp. 124.

[18] Iwe, M.O. (2010). Handbook of Sensory Methods and Analysis. Rojoint Communication Services Ltd., Enugu, pp. 75-78.
[19] Jacobs, B.M. (1999). The Chemical Analysis of Foods and Food Products. (3rd ed.) CBS Publishers and Distributors. New Delhi, India.

[20] Khalil, M., Sulaiman, S. and Boukraa, L. (2010). Antioxidant Properties of Honey and Its Role in Preventing Health Disorder. The Open Nutraceuticals Journal, 3: 6-16.

[21] Nombre, I., Schweitzer, P., Boussim, J. and Millogo, J. and Rasolodimby, J. (2010). Impacts of storage conditions on physicochemical characteristics of honey samples from Burkina Faso. African Journal of Food Science, Vol. 4(7): 458- 463.

[22] Nyau, V., Mwanza, P. and Moonga, B. (2013). Physicochemical qualities of honey harvested from different beehive types in zambia. African Journal of Food Agric. Nutrition and Development, 13(2): 7415-7427.

[23] Onwuka, G.T. (2005) Food Analysis and instrumentation Naphthali Prints Lagos. pp. 28 -74.

[24] Ramanauskiene, R., Stelmakiene, A., Briedis, V., Ivanauskas, L. and Jakstas, V. (2012). The quantitative analysis of biologically active compounds in Lithuanian honey. Food Chemistry, 132: 1544-1548.

[25] Snowdon, A. and Cliver, O. (1996). Review article: Microorganisms in honey, Int. J. Food Microbiol., 31: 1- 26.

[26] USDA. (1985). United States Department of Agriculture. Standards for Honey Grading. USDA, Washington DC.

[27] Vanhanen, L., Emmertz, A. and Savage, G. (2011). Mineral analysis of mono-floral New Zealand honey, Food Chemistry. 128: 236-240.

[28] Viuda-Martos, M., Ruiz-Navajas, Y., Zaldivar-Cruz, J., Kuri, V., Juana Fernandez-Lopez. J., Carbonell-Barrachina, A. and Perez-Alvarez, J. (2010). Aroma profile and physicochemical properties of artisanal honey from Tabasco, Mexico. International Journal of Food Science and Technology, 45: 1111-1118.

[29] Wardy, W., Saalia, F., Steiner-Asiedu, M., Budu A. and SefaDedeh, S. (2009). A comparison of some physical, chemical and sensory attributes of three pineapple (Ananas comosus) varieties grown in Ghana. Afr. J. Food Sci. 3(1):022-025. 